\title{
Chapter 6 \\ Importance of Extracellular Enzymes \\ for Biogeochemical Processes in Temporary \\ River Sediments during Fluctuating Dry-Wet \\ Conditions
}

\author{
Annamaria Zoppini and Jürgen Marxsen
}

\subsection{Introduction}

The special hydrological circumstances that characterize temporary rivers (Fig. 6.1) make them particularly sensitive to environmental alterations. Temporary waters are found throughout the world and include intermittent streams and ponds, episodic rain puddles and seasonal limestone lakes. These natural bodies of water experience a recurrent dry phase of varying duration and spatial extent (Uys and O'Keeffe 1997). Temporary waters are widespread in semi-arid regions worldwide where they play an important role as water sources (e.g., water supply, irrigation and hydroelectric power generation). Climate change represents an emerging problem for these ecosystems by increasing the frequency and duration of drought periods, with potentially important effects on fluvial biogeochemical processes.

From the examination of new findings from the past 6 years of research the Intergovernmental Panel on Climate Change Working Group I (IPCC WGI 2007) concluded that warming of the climate system is unequivocal. An ensemble of 12 climate models (Milly et al. 2005) projects changes in stream flow with 10-30\% decreases in runoff in southern Europe by the year 2050. This trend has already been experienced over the last century not only in the Mediterranean basins (WFD/ EUWI 2006), but also in streams and rivers in temperate European regions. Here decreasing runoffs and extended periods of desiccation have been observed, especially in headwaters (Wilby et al. 2006; Sutherland et al. 2008).

\footnotetext{
A. Zoppini $(\square)$

Istituto di Ricerca Sulle Acque, Consiglio Nazionale delle Ricerche, Area della Ricerca di Roma 1, via Salaria Km 29.300, CP10, 00015 Monterotondo, Roma, Italy

e-mail: zoppini@irsa.cnr.it

J. Marxsen

Limnologische Fluss-Station des Max-Planck-Instituts für Limnologie, 36110 Schlitz, Germany Institut für Allgemeine und Spezielle Zoologie, Tierökologie, Justus-Liebig-Universität Gießen, Heinrich-Buff-Ring 26-32, 35392 Gießen, Germany
} 


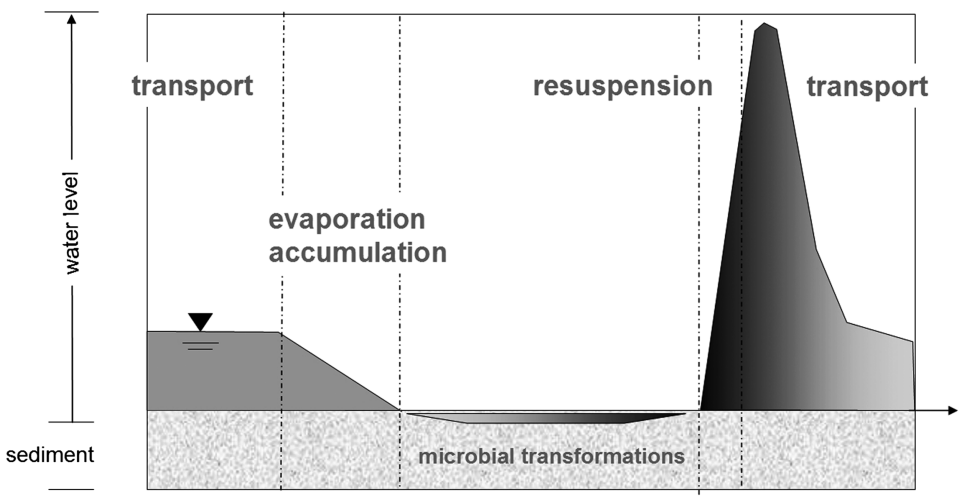

Fig. 6.1 Changes in hydrological conditions in temporary rivers (after Kirkby and Froebrich (2006), modified)

Temporary rivers are the dominant surface water bodies in the Mediterranean region although they are rarely monitored. Until recently dry reaches have been described as "biologically inactive" (Stanley et al. 1997) and there is still little information available on the biogeochemical processes. Tzoraky et al. (2007) observed that in semi-arid catchments the channel bed processes continue even at a low level (40\%) of sediment moisture. As a result, the first water flush entering into contact with sediments after a drought period could be extremely modified in its chemistry compared to the base flow, causing in turn drastic modifications in the chemistry of receiving water-bodies (e.g., lakes, rivers, and coastal waters) (Fig. 6.1).

Aquatic sediments act as a sink and source of nutrients. Microbial degradation and transformation of the organic matter deposited in a river channel bed are key processes with regard to the carbon cycling in the lotic food web, which links sedimentary organic matter to the upper level of the community, including carnivores (Fischer and Pusch 2001; Findlay et al. 2003; Mulholland 2003; Marxsen 2006). Via the microbial food chain, complex organic substrates are solubilized by extracellular enzymes in a series of steps from particulate organic matter to high molecular weight dissolved organic carbon and low molecular weight substrates (Chrost 1991). A strong coupling between bacterial activities and deposition of organic material in sediment has been found for both marine and freshwater systems (Sander and Kalff 1993; Goedkoop et al. 1997; Wobus et al. 2003). Hence the efficiency of extracellular enzymes represents a critical step and is able to influence the incorporation of organic carbon into bacterial cells and the consequent transfer to the food chain (Marxsen and Fiebig 1993).

Drying and rewetting are well known climatic factors influencing the physiological status of microbial biomass in soil ecosystems, with significant effects on mineralization (e.g., Raubuch et al. 2002; Griffiths et al. 2003; Mikha et al. 2005). Although benthic microbial processes have been recognized as having an important role in carbon and nutrient flux, few studies have documented the 
response to dry-wet cycles in temporary waters. The exact role of microbes in mediating these processes is still largely unresolved because methodological constraints make it difficult to determine whether the effects are biologically or physically driven. In addition, in situ measurements are very difficult because of high temporal variability and spatial heterogeneity. This issue has been recently addressed by the European Commission through its funding of Research Projects on temporary rivers (TempQsim and Mirage) with the aim to provide advanced tools to significantly improve the efficiency of integrated water management in Mediterranean semiarid river catchments. This action has encouraged experimental studies on the role of the benthic microbial community in carbon, nutrient and energy flux during drastic changes in water availability (Tzoraky et al. 2007; Amalfitano et al. 2008; Fazi et al. 2008; Zoppini et al. 2010).

\subsection{The Response of Benthic Microbial Communities to Drought: A Matter of Survival}

Drought has been cited as the most serious of natural disasters as regards loss of life and its impact on agricultural production and economics (Wilhite 2000), although it is a natural feature of aquatic ecosystems in most regions of the world (McMahon and Finlayson 2003).

Temporary waters result in sediment desiccation during an extended period of the year with the consequence of exposing the benthic organisms living there to the air. Biota that inhabits these ecosystems must be morphologically, physiologically and behaviorally adaptable to survive such conditions until the first flood arrives.

Desiccation has been reported to alter the chemistry (e.g., De Groot and Van Wijck 1993) and mineralogy (e.g., Baldwin 1996) of the sediment or soil and kills up to three-quarters of the microbes (e.g., Qiu and McComb 1995). In semiarid regions of the planet drought events have a major effect on benthic community functions, including a delay in litter decomposition together with a decrease in invertebrate density (Pinna and Basset 2004; Fonnesu et al. 2004; Larned et al. 2007).

Tolerance mechanisms to desiccation are poorly understood despite the fact that numerous prokaryotic and eukaryotic organisms are capable of surviving more or less complete dehydration. Drying-rewetting imposes physiological constraints that few genera of bacteria, called anhydrobiotes, can tolerate (Potts 1994; Billi and Potts 2002). Bacteria can cope with this problem through strategies such as forming polymers and spores with the ability to resist physical blows. The production and storage of intracellular solutes, like amino acids and low molecular weight carbohydrates, for acclimatizing to low water conditions (Halverson et al. 2000), is especially important for Gram-negative bacteria, which are unable to form spores and are more susceptible than Gram-positives to disruption by osmotic stress because of their less stable cell walls (Fierer et al. 2003; Schimel et al. 2007). 
Examples of spore-forming bacteria are quite widespread among Gram-positive bacteria and they colonize various habitats, including the aquatic environment. In their dormant state, spores have no detectable metabolism although recent findings indicate that dormant bacterial spores, belonging to the genus Bacillus, can significantly influence the distribution of heavy metals in the sedimentary marine environment by enzymatic catalysis (Francis and Tebo 2002; Dick et al. 2006). Moreover over the long term (millions of years) catalase was found in freezedried permafrost samples (Gilichinsky et al. 1992), while in deep-sea sediments enzyme activity was detected even in a 124,000 year-old sapropel layer (Coolen and Overmann 2000). Overall, these studies suggest that the commonly held view that bacteria in the dormant state are inactive should be revised.

Lowland river-floodplain systems are characterized by a high degree of variability where inundation marks the shift from a terrestrial ecosystem to an aquatic one. In these systems partial drying of wet (previously inundated) sediments results in an increased sediment affinity for phosphorus and produces a zone where there is nitrification coupled with denitrification causing a reduction of nutrient availability (Baldwin and Mitchell 2000). A complete desiccation of sediments may lead to the death of bacteria (and subsequent mineralization of nutrients), a decrease in the affinity of $\mathrm{P}$ for iron minerals, a decrease in microbial activity and a cessation of all anaerobic bacterial processes (e.g., denitrification).

For semi-permanent stream sediments Rees et al. (2006) showed that changes in microbial community structure were preserved even one month after rewetting, with a significant difference from the pre-drought and drought microbial communities.

The functional properties of microbial communities were investigated in the sediment of ephemeral rivers (Larned et al. 2007). Non-specific esterase activity, used as an assay for total enzyme activity, was negatively related to the dry period length. The esterase activity decreased by a negative exponential model in the dry periods of 1-7 days accompanied by decreasing respiration rates. Moreover a prolonged period of drought (up to 417-days) further affected esterase activity, reducing the rates by an order of magnitude to close to the detection limit.

Extracellular enzymes may be stable in dry soils or aquatic biofilms for weeks. For phosphatases Perez-Mateos et al. (1991) observed that $65 \%$ of indigenous enzymes remained active after 50 days of soil storage at $22^{\circ} \mathrm{C}$, while Romaní and Sabater (1997) found that extracellular enzyme activity recovered immediately in stromatolitic riverine communities when rewetted after a summer drought.

Benthic cyanobacterial mats from marshes of northern Belize, an oligotrophic environment, are exposed to extreme conditions in terms of hydrology, nutrient availability and salinity (Sirová et al. 2006). In the cyanobacterial mats alkaline phosphatase exhibited the highest extracellular enzyme activity, followed by leucineaminopeptidase, arylsulphatase, and $\beta$-glucosidase. During the period of drought dry mats retained the same level of potential phosphatase activity after 10 weeks of desiccation (350-450 $\mu \mathrm{mol} \mathrm{MUF} \mathrm{g}^{-1}$ ash free dry weight $\mathrm{min}^{-1}$ ). In this environment the preservation of enzyme activity may be favored by the levels of polysaccharide-rich extracellular polymeric substances (EPS) that characterise benthic 
cyanobacterial mats. Most of the phosphatase activity, visualized using artificial $\mathrm{ELF}^{\circledR} 97$ phosphate, appeared free and located in the EPS matrix throughout the mat, with a decoupling from its source in both space and time.

Many studies on the effect of droughts on benthic microorganisms encounter difficulties in disentangling the relative effects of the spatial and temporal extents of low flows and of these from the river bed drying pattern. The alternative approach to gathering information is to simulate a drought event in the laboratory.

Amalfitano et al. (2008) collected wet sediments from four temporary European rivers and let them dry under controlled conditions until complete desiccation. Despite the different origin of the microbial communities the responses of structural and functional parameters to drought were very similar (Fig. 6.2). Bacterial carbon production exponentially decreased, nearly ceasing in dry conditions, followed by a slower decrease in bacterial abundance, with an overall reduction of $74 \%$. By the end of the experiment, live cells (14\% of the initial value) were depressed in their main metabolic functions. Hence a conspicuous number of live cells were still abundant at the end of the experiment, but mostly depressed in their metabolic activity. As a result, the significant decrease in per-cell production resulted in a very substantial increase in the community turnover time. Community composition shifted, with an increase in Alpha- and Betaproteobacteria when sediment was dried. In the same experiment extracellular enzyme activities, measured fluorometrically (Wobus et al. 2003), involved in P, N, and C cycling were weakly or not at all affected by the progressive decreasing of water availability (Zoppini 2007). Aminopeptidase activity was affected by drying and displayed a slow decreasing trend in all tested rivers although it preserved between 40 and $60 \%$ of the initial rates in dry sediments (Fig. 6.3). Overall the capacity of alkaline phosphatase to hydrolyze phosphorilated organic matter did not change significantly during the progressive loss of moisture: only one in four tested sediments (the river Krathis) showed a negative trend with desiccation but still preserved $80 \%$ of its initial capacity during dry conditions. Similarly the hydrolyzing capacity of polymers like polysaccharides and lipids ( $\beta$-glucosidase and lipase activities) was preserved under drought conditions without showing any significant trend. This enzyme activity survival capacity recalls mechanisms found in desiccation-tolerant bacterial cells capable of accumulating proteins, of which many are able to remain stable (Billi and Potts 2002), or the capacity of polysaccharides-rich extracellular polymeric substances (EPS) to favor enzyme preservation (Sirová et al. 2006).

To sum up the data, microbial communities are significantly affected by water stress conditions and there are changes in microbial community structure with a drastic reduction of cell abundance, vitality and metabolic activity. Hydrolytic enzymes constitute an exception to this trend. They are probably preserved even if the cells in which they originated become non-viable. We postulate that the preservation of these enzymes represents an important mechanism for the fast recovery of surviving microbial cells after drought. If the hydrolysis of organic matter continues in the dry sediment we can infer that the pool of organic compounds contained in the first water flush could be enriched with labile nutrients that accumulate in the sediments as bacteria are died or temporarily 

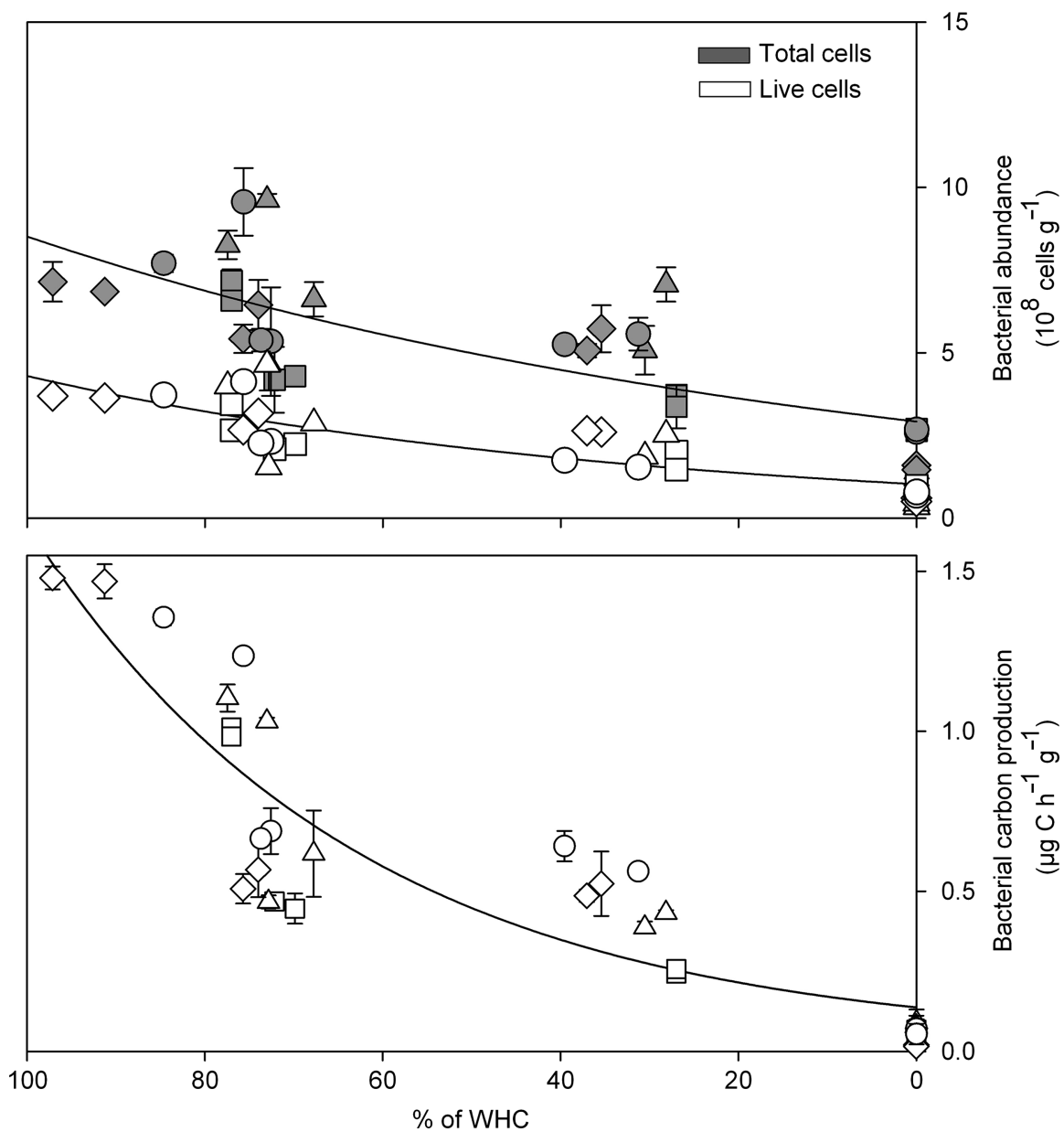

Fig. 6.2 Total and live (Live/Dead ${ }^{\circledR}$ BacLight ${ }^{\mathrm{TM}}$ dye technique) bacterial cell abundance (top panel) and carbon production $\left({ }^{3} \mathrm{H}\right.$-Leucine inc.) (bottom panel) versus sediment water content, expressed as a percentage of sediment water hold capacity (WHC). Note the $x$-axis reverse scale: $100 \%$ identifies wet sediment at the beginning of the experiment, $0 \%$ corresponds to the ending dry sediment. All data are normalized to grams of dry sediment. Error bars indicate standard deviations of three independent measurements. Regression curves are shown originating from temporary rivers (total cell abundance: $r^{2}=0.69, P<0.05$; live cell abundance $r^{2}=0.76, P<0.05 ;{ }^{3} \mathrm{H}$ leucine inc. $r^{2}=0.79, P<0.05$ ). (square Tagliamento, Italy; triangle Krathis, Greece; diamond Mulargia, Italy; circle Pardiela, Portugal). (after Amalfitano et al. (2008), modified)

inactive. However, in the case of a complete stop of extracellular enzyme activity during extreme dryness, enzymes are able to become active immediately upon rewetting (Marxsen et al. 2010), thus resulting in immediate delivery of these compounds. 

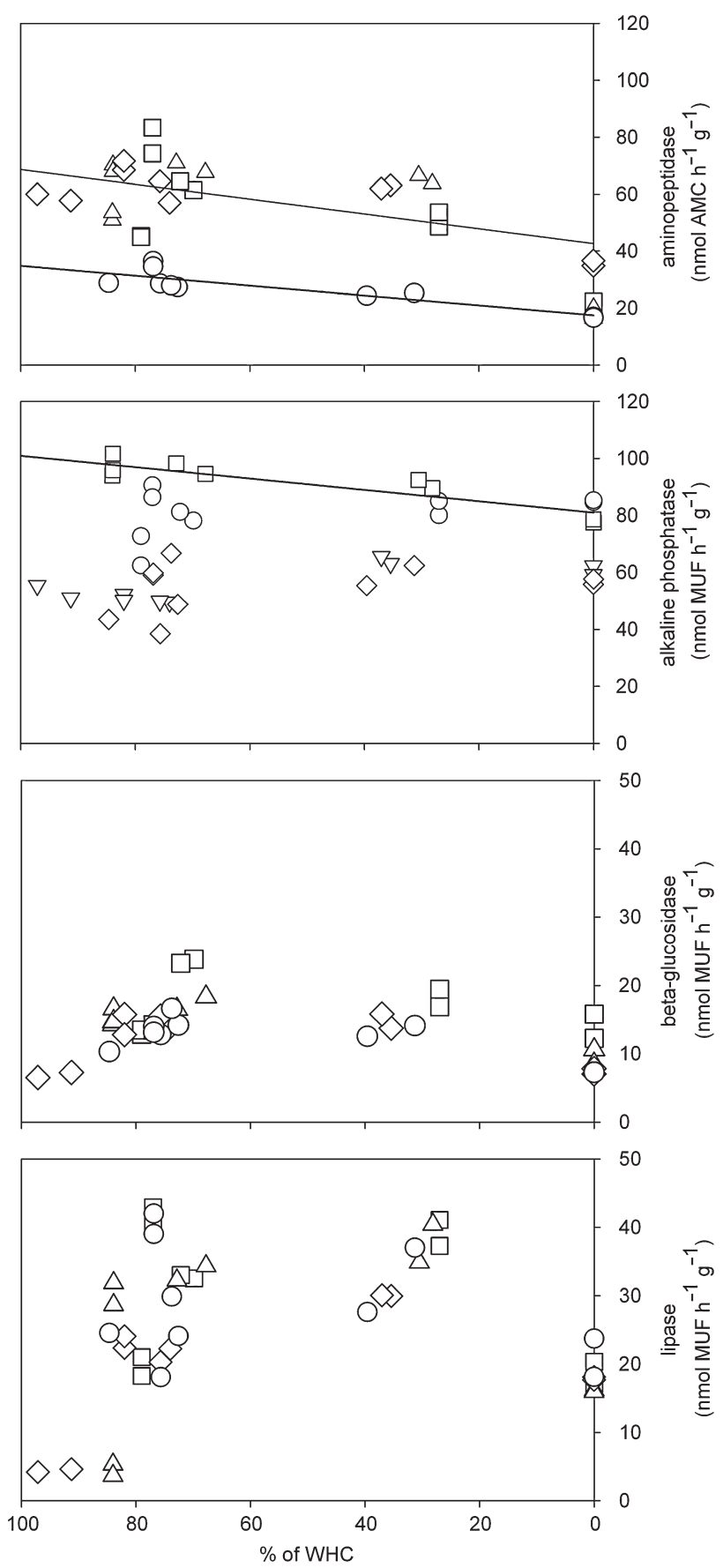

Fig. 6.3 Extracellular enzyme activities versus sediment water content expressed as percentage of sediment water hold capacity (WHC) (see Fig. 3 for symbols). All data are normalized to gram of 


\subsection{Benthic Microbial Community Awakening After Flooding}

The intense run-off and flushing associated with the heavy storms typically occur shortly after the end of a dry period. These events can severely impact microbial distribution as river discharges can increase by several orders of magnitude with respect to their regular flow (Holmes et al. 1998).

Inundation of previously dry river reaches can trigger ecological "hot moments" during which biogeochemical reactions or biological processes begin to accelerate after long quiescent periods (McClain et al. 2003). Inundation can activate microbial and algal cells, delivers chemical substrates to reaction sites, and stimulates enzymecontrolled nutrient transformations and organic matter mineralization (Baldwin and Mitchell 2000; Burns and Ryder 2001; Belnap et al. 2005; Romanì et al. 2006).

Several findings suggest that biota response to inundation depends on the duration of the preceding dry phase (Baldwin and Mitchell 2000; Larned et al. 2007). After 17 days of inundation esterase enzyme activity in sediments that had been dry for 256-523 days was comparable to the potential activity in non-inundated sediments from a similar dry-period range (Larned et al. 2007). After the same dry-period range and 17 days of inundation there was no detectable relationship between sediment respiration rate and dry period duration, although rates tended to be higher for inundated sediments than for non-inundated sediments.

Strong temporal peaks in enzyme activity were observed in sediments within 7 days following inundation (Burns and Ryder 2001). The short response time of $\alpha$ - and $\beta$-glucosidase activities after $24 \mathrm{~h}$ flooding suggests that even short pulses in high flows may stimulate bacterial activity as dissolved organic carbon loads also peak at this time. However, a longer wetting time may be needed to drive hydrolysis of the proteins, fatty acids and longer chain polysaccharides. This indicates a rapid use of available carbon by microbial communities. A general decline in enzyme activity rates was found in the 21 days following the first week from inundation, which was thought to be the result of substrate limitation within the flooded cores or inhibition by hydrolysis end products.

There have been laboratory-scale experiments conducted on dry sediment simulating an inundation event in order to demonstrate the role of sediments as a source of microbial populations, and related activities, in "first-flush" water (Fazi et al. 2008).

Within $9 \mathrm{~h}$ after inundation of dry sediments, benthic bacteria colonized the overlaying water and approximately $20 \%$ of total cells exhibited DNA de novo synthesis (bromodeoxyuridine-positive). The primary microbial colonizers of the overlaying water - as determined by $16 \mathrm{~S}$ rRNA gene sequence analysis - were related to at least six different phylogenetic lineages of Bacilli, a group with many

Fig. 6.3 (continued) dry sediment. Data reported are from duplicated microcosms and single values are means of four measurements. Regression curves are shown (aminopeptidase $r^{2}=0.78$ Pardiela river and $r^{2}=0.52$ in the rest of rivers, $P<0.05$; alkaline phosphatase $r^{2}=0.80$, $P<0.05$ ) (Zoppini 2007) 
spore-forming members (Onyenwoke et al. 2004), and Alphaproteobacteria (Brevundimonas spp. and Caulobacter spp.). The microbial awakening was accompanied by $\mathrm{C}$ production rates similar to those measured in highly productive eutrophic systems with a prevalence of biomass synthesis $\left({ }^{3} \mathrm{H}\right.$-leucine incorporation) over cell division $\left({ }^{3} \mathrm{H}\right.$-thymidine incorporation) (Fig. 6.4). Significant extracellular enzyme activities were also observed: within $28 \mathrm{~h}$ after inundation aminopeptidase activity reached $70 \%$ of the peak value, which was after $72 \mathrm{~h}\left(431 \mathrm{nmol} \mathrm{MCA} \mathrm{L}{ }^{-1} \mathrm{~h}^{-1}\right)$, while alkaline phosphatase activity reached $83 \%$ (99 nmol MUF $1^{-1} \mathrm{~h}^{-1}$ ). The analysis of the aminopeptidase to alkaline phosphatase activity ratio showed the different role played by these enzymes in the metabolic awakening of bacterial cells. The lower hydrolysis rate of organic phosphorus compared to proteins, described by the increasing AMA:APA ratio, indicated a slower P-remobilization compared to N-remobilization. Aminopeptidase and alkaline phosphatase activities were also significantly correlated to bacterial carbon and cell production $(P<0.01$; $n=12$ ). This confirmed the key role played by extracellular enzymes in making available organic compounds for both the synthesis of intracellular proteins and the production of new biomass.

A more advanced tool for studying metabolic properties in streambed sediments is represented by the perfused core technique (Marxsen and Fiebig 1993). The application of this approach enables the acquisition of new information on the time and mode of recovery of benthic microbial communities after flooding without major disturbances of the sediment core (Marxsen et al. 2010). The response of two river sediments, originating from semi-arid (Mulargia, Italy) and temperate (Breitenbach, Germany) climatic regions, were analyzed. Both sediments were similar in microbial community composition, determined via CARD-FISH, in that they were dominated by Betaproteobacteria (39-45\%) and Alphaproteobacteria (27-31\%). However, the Mulargia sediment contained a higher percentage of Gram-positive bacteria (24\%) than the Breitenbach one (9\%). After rewetting bacterial cell abundances did not change significantly from their initial values, which were similar to those observed in the wet sediments (Mulargia $10 \times 10^{8}$ cells $\mathrm{mL}^{-1}$ sediment and Breitenbach $30 \times 10^{8}$ cells $\mathrm{mL}^{-1}$ sediment) (Fig. 6.5).

The functional awakening of the microbial community was marked by rapid bacterial carbon production, which reached the maxima rates within $48 \mathrm{~h}$ in both sediments (Fig. 6.5). This trend was also accompanied by a rapid increase in extracellular enzyme activities (Fig. 6.6). A few hours after flooding aminopeptidase activity reached about half the level measured in non-desiccated sediments. This activity increased further until the end of the experiment, when values reached those measured in unaffected sediments. Alkaline phosphatase was reactivated within a few hours although in both sediments it underwent a progressive decrease. These experimental findings are in accordance with previous observations. Alkaline phosphatase is involved in phosphorous remobilization and its activity is proportional to phosphorous demand. It has been estimated that $30-60 \%$ of the microbial biomass carbon contained in the soil may be released during an individual rewetting event along with water soluble phosphorous deriving, for example, from the 

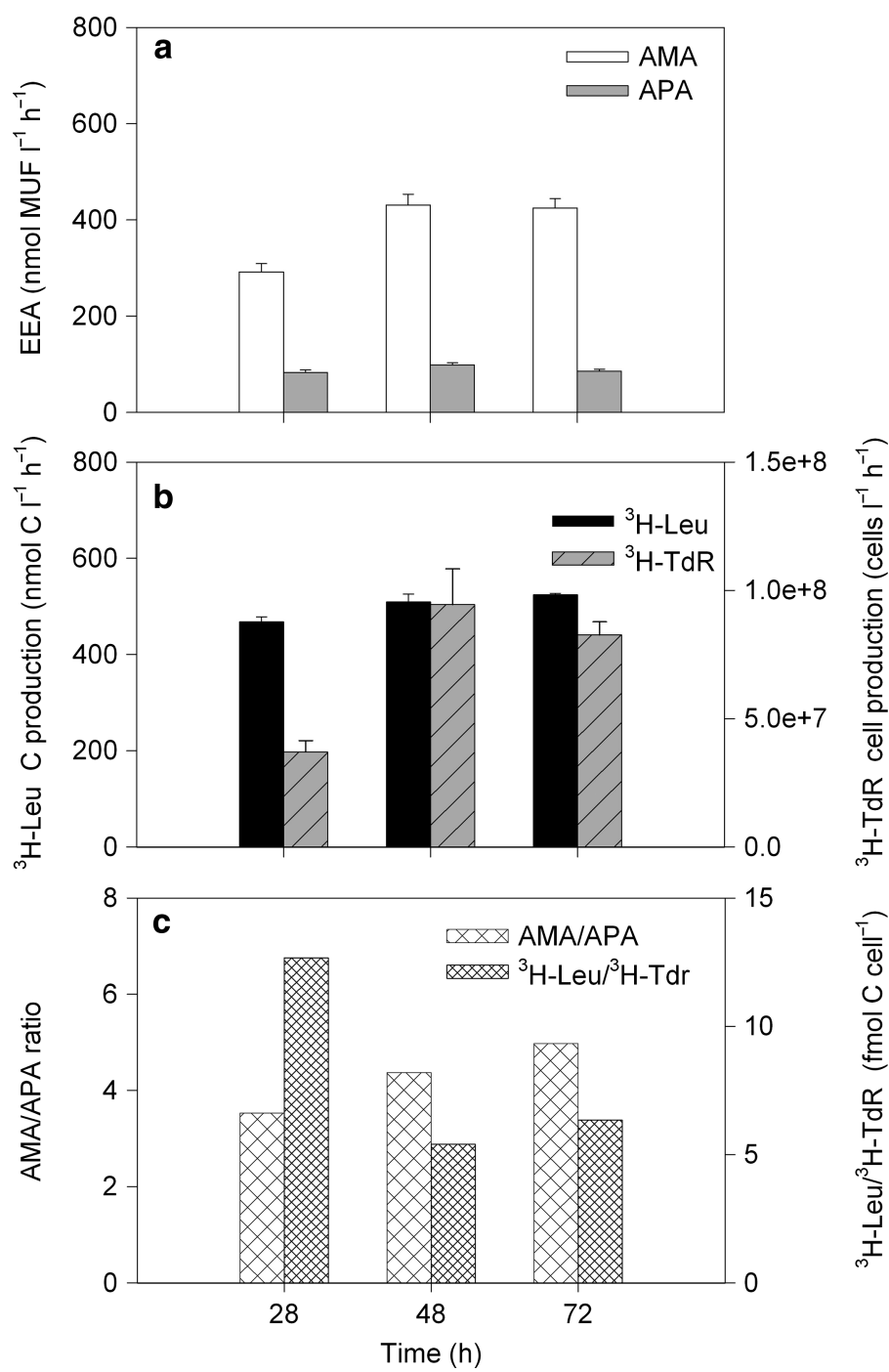

Fig. 6.4 (a) Extracellular enzyme activities (AMA, aminopeptidase activity; APA, alkaline phosphatase activity). (b) Bacterial carbon production $\left({ }^{3} \mathrm{H}\right.$-leucine inc.) and cell production $\left({ }^{3} \mathrm{H}\right.$ thymidine inc.). (c) The AMA to APA ratios and ${ }^{3} \mathrm{H}-\mathrm{Leu}$ to ${ }^{3} \mathrm{H}-\mathrm{TdR}$ ratios. Data are means and standard deviation of duplicate measurements from three independent microcosms (after Fazi et al. (2008), modified)

microbial cell rupture caused by osmotic shock (Kieft et al. 1987; Halverson et al. 2000; Baldwin and Mitchell 2000; Austin et al. 2004).

The hydrolysing activity related to polysaccharides ( $\beta$-glucosidase) and lipids (lipase) also showed a fast recovery with differences among sediments (Fig. 6.6). The high activity levels measured at the beginning of rewetting in both 

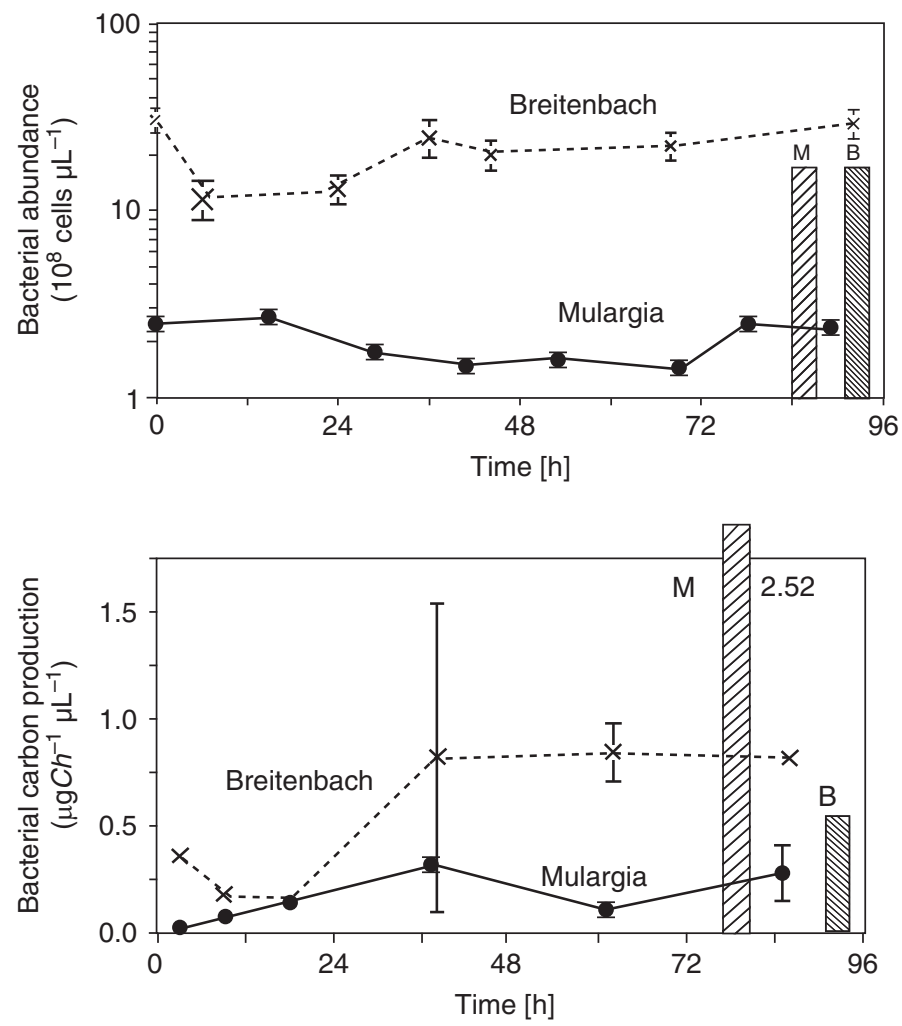

Fig. 6.5 (a) Bacterial abundance and (b) bacterial carbon production $\left(\mathrm{BCP},{ }^{14} \mathrm{C}\right.$-leucine incorporation) after rewetting of desiccated streambed sediments. Average values and standard deviations are shown (if not visible, sd is hidden behind symbols). The columns give data from non-desiccated sediments ( $B$ Breitenbach, $M$ Mulargia) (after Marxsen et al. (2010), modified)

environments, especially those for enzymes involved in polymer degradation ( $\beta$ glucosidase, peptidase and lipase), can be taken as an indication of outlasting of extracellular enzymes during drought, confirming previous findings on the preservation of enzymes during drying (Sirová et al. 2006; Fazi et al. 2008; Zoppini 2007). Their activities can play an important role in fuelling the bacterial metabolism as they supply organic substrates rich in energy (glucose and fatty acids) and amino acids ready to use for synthesising new biomass.

\subsection{Conclusions}

Overall our understanding of the effect of dry-wet conditions on the ecology of temporary rivers is still limited. From the information available on the functional properties of microbial communities we can infer that their role in carbon, nutrient and energy flux in water stress conditions is important. 

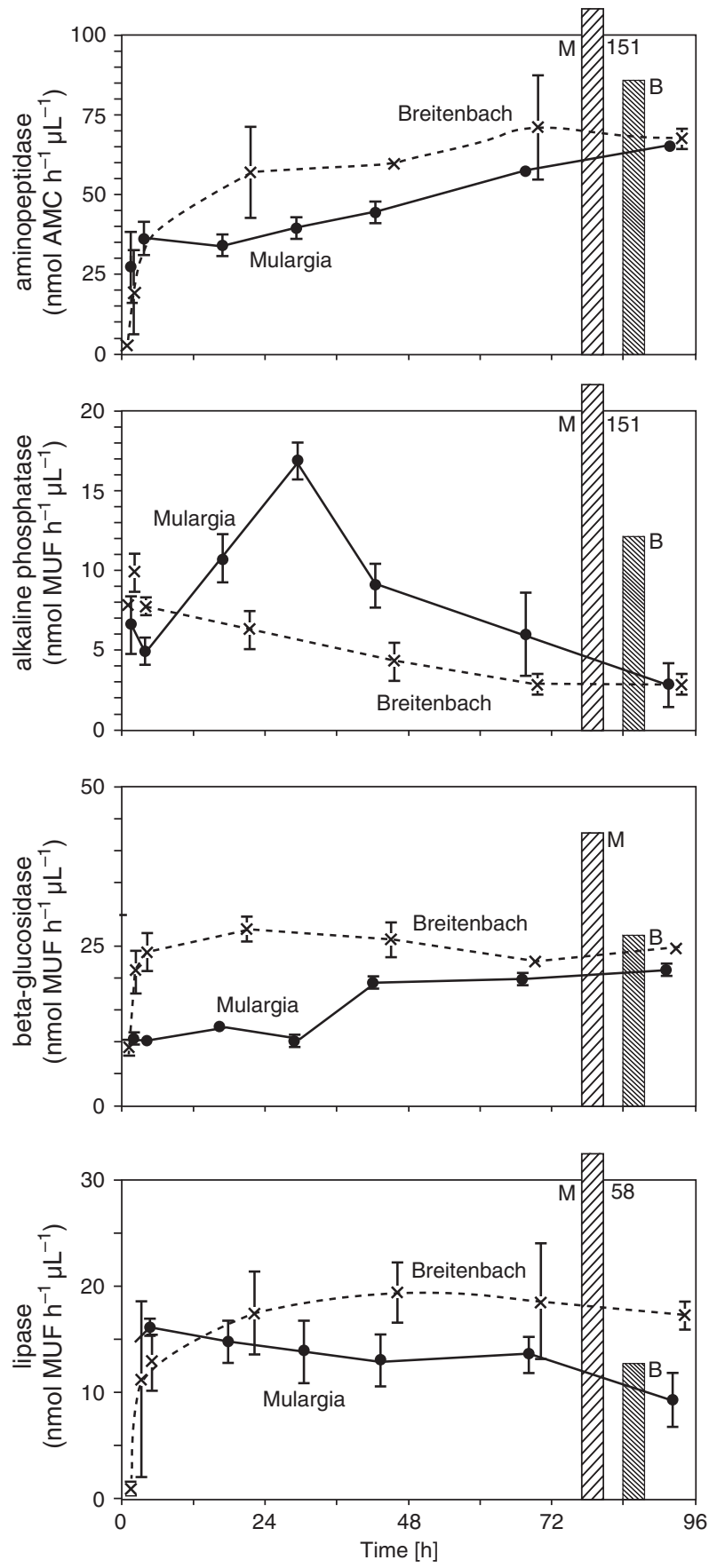

Fig. 6.6 Extracellular enzyme activities after rewetting of desiccated streambed sediments. Average values and standard deviations are shown (if not visible, sd is hidden behind symbols). The columns give data from non-desiccated sediments ( $B$ Breitenbach, $M$ Mulargia) (after Marxsen et al. (2010), modified) 
A common feature of rewetted sediments (and soil) is a large flush of mineral phosphorous and nitrogen in the initial phase. Microbial communities can significantly contribute to this via different mechanisms. The preservation of enzymes during periods of drought, even in prohibitive conditions for the rest of the microbial metabolism, determines an excess of labile organic matter and nutrients ready to be taken up later by bacteria at water arrival or to be delivered immediately upon rewetting. In this scenario the first flood delivers labile low molecular organic matter and nutrients to the receiving water bodies with the potential to accelerate microbial processes and affect water quality (i.e., the onset of anoxia).

The fast resumption of enzyme activity favors the rapid re-establishment of sediment functions due to aquatic microbial communities. It appears that dryingrewetting plays a key role in a number of metabolic processes in temporary rivers and the length of drought periods is important in affecting biogeochemical cycling.

Increased periods of drought, due to climate change, could thus represent a bottleneck for bacterial communities living in temporary waters and they will need to adopt their metabolic strategies to survive them.

\section{References}

Amalfitano S, Fazi S, Zoppini A, Barra Caracciolo A, Grenni P, Puddu A (2008) Responses of benthic bacteria to experimental drying in sediments from Mediterranean temporary rivers. Microb Ecol 55:270-279

Austin AT, Yahdjian L, Stark JM, Belnap J, Porporato A, Norton U, Ravetta DA, Schaeffer SM (2004) Water pulses and biogeochemical cycles in arid and semiarid ecosystems. Oecologia 141:221-235

Baldwin DS (1996) Effects of exposure to air and subsequent drying on the phosphate sorption characteristics of sediments from a eutrophic reservoir. Limnol Oceanogr 41:1725-1732

Baldwin DS, Mitchell AM (2000) The effects of drying and re-flooding on sediment and soil nutrient dynamics of lowland river-floodplain systems: a synthesis. Regulated Rivers: Res Manag 16:457-467

Belnap J, Welter JR, Grimm NB, Barger N, Ludwig JA (2005) Linkages between microbial and hydrologic processes in arid and semiarid watersheds. Ecology 86:298-307

Billi D, Potts M (2002) Life and death of dried prokaryotes. Res Microbiol 153:7-12

Burns A, Ryder DS (2001) Response of bacterial extracellular enzymes to inundation of floodplain sediments. Freshw Biol 46:1299-1307

Chrost RJ (1991) Environmental control of the synthesis and activity of aquatic microbial ectoenzymes. In: Chrost RJ (ed) Microbial enzymes in aquatic environments. Springer, New York, pp 29-59

Coolen MJL, Overmann J (2000) Functional exoenzymes as indicators of metabolically active bacteria in 124,000-year-old sapropel layers of the eastern Mediterranean sea. Appl Environ Microbiol 66:2589-2598

De Groot C, Van Wijck C (1993) The impact of desiccation of a freshwater marsh (Garcines Nord, Camargue, France) on sediment-water-vegetation interactions. Part one: the sediment chemistry. Hydrobiologia 252:83-94

Dick GJ, Lee YE, Tebo BM (2006) Manganese(II)-oxidizing bacillus spores in Guaymas Basin hydrothermal sediments and plumes. Appl Environ Microbiol 72:3184-3190

Fazi S, Amalfitano S, Piccini C, Zoppini A, Puddu A, Pernthaler J (2008) Colonization of overlaying water by bacteria from dry river sediments. Environ Microbiol 10:2760-2772 
Fierer N, Schimel JP, Holden PA (2003) Influence of drying-rewetting frequency on soil bacterial community structure. Microb Ecol 45:63-71

Findlay SEG, Sinsabaugh RL, Sobczak WV, Hoostal M (2003) Metabolic and structural response of hyporheic microbial communities to variations in supply of dissolved organic matter. Limnol Oceanogr 48:1608-1617

Fischer H, Pusch M (2001) Comparison of bacterial production in sediments, epiphyton and the pelagic zone of a lowland river. Freshw Biol 46:1335-1348

Fonnesu A, Pinna M, Basset A (2004) Spatial and temporal variations of Detritus breakdown rates in the river Flumendosa Basin (Sardinia, Italy). Int Rev Hydrobiol 89:443-452

Francis CA, Tebo BM (2002) Enzymatic manganese(II) oxidation by metabolically dormant spores of diverse Bacillus species. Appl Environ Microbiol 68:874-880

Gilichinsky DA, Vorobyova EA, Erokhina LG, Fyodorov-Dayvdov DG, Chaikovskaya NR (1992) Long-term preservation of microbial ecosystems in permafrost. Adv Space Res 12:255-263

Goedkoop W, Gullberg KR, Johnson RK, Ahlgren I (1997) Microbial response of a freshwater benthic community to a imulated diatom sedimentation event: interactive ejects of benthic fauna. Microb Ecol 34:131-143

Griffiths RI, Whiteley AS, O’Donnell AG, Bailey MJ (2003) Physiological and community responses of established grassland bacterial populations to water stress. Appl Environ Microbiol 69:6961-6968

Halverson LJ, Jones TM, Firestone MK (2000) Release of intracellular solutes by four soil bacteria exposed to dilution stress. Soil Sci Soc Am J 64:1630-1637

Holmes RM, Fisher SG, Grimm NB, Harper BJ (1998) The impact of flash floods on microbial distribution and biogeochemistry in the parafluvial zone of a desert stream. Freshw Biol 40:641-654

IPCC (2007) Climate change 2007: the physical science basis. Contribution of working group I to the fourth assessment report of the intergovernmental panel on climate change. Cambridge University Press, Cambridge, 996

Kieft T, Soroker E, Firestone M (1987) Microbial biomass response to a rapid increase in water potential when dry soil is wetted. Soil Biol Biochem 19:119-126

Kirkby M, Froebrich J (2006) Introduction. In: Froebrich J, Bauer M (eds) Critical issues in the water quality dynamics of temporary waters - evaluation and recommendations from the TempQsim Project. Booklet - enduser summary. Institute for water quality and waste management, University of Hannover, Hannover, pp 8-11

Larned ST, Datry T, Robinson C (2007) Invertebrate and microbial responses to inundation in an ephemeral river reach in New Zealand: effects of preceding dry periods. Aquat Sci 69:554-567

Marxsen J (2006) Bacterial production in the carbon flow of a central European stream, the Breitenbach. Freshw Biol 51:1838-1861

Marxsen J, Fiebig DM (1993) Use of perfused cores for evaluating extracellular enzyme activity in stream-bed sediments. FEMS Microbiol Ecol 13:1-11

Marxsen J, Zoppini A, Wilczek S (2010) Microbial communities in streambed sediments recovering from desiccation. FEMS Microb Ecol 71:374-386

McClain ME, Boyer EW, Dent CL, Gergel SE, Grimm NB, Groffman PM, Hart SC, Harvey J, Johnston CA, Mayorga E, McDowell WH, Pinay G (2003) Biogeochemical hot spots and hot moments at the interface of terrestrial and aquatic ecosystems. Ecosystems 6:301-312

McMahon TA, Finlayson BL (2003) Droughts and anti-droughts: the low-flow hydrology of Australian rivers. Freshw Biol 48:1147-1160

Mikha MM, Riceb CW, Millikenc GA (2005) Carbon and nitrogen mineralization as affected by drying and wetting cycles. Soil Biol Biochem 37:339-347

Milly PCD, Dunne KA, Vecchia AV (2005) Global pattern of trends in streamflow and water availability in a changing climate. Nature 438:347-350

Mulholland PJ (2003) Large-scale patterns in dissolved organic carbon concentration, flux and sources. In: Findlay SE, Sinsabaugh RL (eds) Aquatic ecosystems, Interactivity of dissolved organic matter. Academic, Elsevier, San Diego, pp 139-159 
Onyenwoke RU, Brill JA, Farahi K, Wiegel J (2004) Sporulation genes in members of the low G+C Gram-type- positive phylogenetic branch (Firmicutes). Arch Microbiol 182:182-192

Perez-Mateos M, Busto MD, Rad JC (1991) Stability and properties of alkaline phosphate immobilized by a rendzina soil. J Sci Food Agr 55:229-240

Pinna M, Basset A (2004) Summer drought disturbance on plant detritus decomposition processes in three River Tirso (Sardinia, Italy) sub-basins. Hydrobiologia 522:311-319

Potts M (1994) Desiccation tolerance of prokaryotes. Microbial Rev 58:755-805

Qiu S, McComb AJ (1995) Planktonic and microbial contributions to phosphorus release from fresh and air-dried sediments. Mar Freshw Res 46:1039-1045

Raubuch M, Dyckmans J, Joergensen RG, Kreutzfeldt M (2002) Relation between respiration, ATP content, and adenilate energy charge (AEC) after incubation at different temperature and after drying and rewetting. J Plant Nutr Soil Sci 165:435-440

Rees GN, Watson GO, Baldwin DS, Mitchell AM (2006) Variability in sediment microbial communities in a semipermanent stream: impact of drought. J North Am Benthol Soc 25:370-378

Romanì AM, Sabater S (1997) Metabolism recovery of a stromatolitic biofilm after drought in a Mediterranean stream. Archiv für Hydrobiologie 140:262-271

Romanì AM, Vazquez E, Butturini A (2006) Microbial availability and size fractionation of dissolved organic carbon after drought in an intermittent stream: biogeochemical link across the stream-riparian interface. Microb Ecol 52:501-512

Sander BC, Kalff J (1993) Factors controlling bacterial production in marine and freshwater sediments. Microb Ecol 26:79-99

Schimel J, Balser TC, Wallenstein M (2007) Microbial stress-response physiology and its implications for ecosystem function. Ecology 8:1386-1394

Sirová D, Vrba J, Rejmánková E (2006) Extracellular enzyme activities in benthic cyanobacterial mats: comparison between nutrient-enriched and control sites in marshes of northern Belize. Aquat Microb Ecol 44:11-20

Stanley EH, Fisher SG, Grimm NB (1997) Ecosystem expansion and contraction in streams. Bioscience 47:427-435

Sutherland WJ, Bailey MJ, Bainbridge IP et al (2008) Future novel threats and opportunities facing UK biodiversity identified by horizon scanning. J Appl Ecol 45:821-833

Tzoraky O, Nikolaidis NP, Amaxidis Y, Skoulikidis NTH (2007) In-stream biogeochemical processes of a temporary river. Environ Sci Technol 41:1225-1231

Uys CM, O'Keeffe J (1997) Simple words and fuzzy zones: early directions for temporary river research in South Africa. Environ Manage 21:517-531

WFD/EUWI (2006) Mediterranean joint process WFD/EUWI, Water Scarcity Drafting Group, Tool Box (Best practices) on water scarcity. Draft Version 9, to be modified, 13 Feb 2006

Wilby RL, Whitehead PG, Wade AJ, Butterfield D, Davis RJ, Watts G (2006) Integrated modelling of climate change impacts on water resources and quality in a lowland catchment: River Kennet, UK. J Hydrol 330:204-220

Wilhite DA (2000) Drought as a natural hazard. Concept and definition. In: Wilhite DA (ed) Drought: a global assessment, vol 1. Routledge, London, New York, pp 3-18

Wobus A, Bleul C, Maassen S, Scheerer C, Schuppler M, Jacobs E, Röske I (2003) Microbial diversity and functional characterization of sediments from reservoirs of different trophic state. FEMS Microbiol Ecol 46:331-347

Zoppini A (2007) Extracellular enzyme activity in temporary river sediments under drying and rewetting conditions. In: Dick RP (ed) Proceedings of the third international conference, enzymes in the environment: ecology, activity and applications. Viterbo (Italy), 15-19 July 2007, p 29

Zoppini A, Amalfitano S, Fazi S, Puddu A (2010) Dynamics of a benthic microbial community in a riverine environment subject to hydrological fluctuations (Mulargia River, Italy). Hydrobiologia (in press) DOI: 10.1007/s10750-010-0199-6 